Emergence, transition, and continuity: Resource Commodity Production Pathways in Northeastern British Columbia, Canada

Greg Halseth, University of Northern British Columbia

Laura Ryser, University of Northern British Columbia

Sean Markey, Simon Fraser University

and

Alex Martin, University of Northern British Columbia

Revised manuscript, resubmitted to Journal of Rural Studies

SI: New Regional Economies

Draft March 7, 2014

This is an accepted / original manuscript of an article published by Elsevier in the Journal of Rural Studies in 2014, available at: https://doi.org/10.1016/i.jrurstud.2014.03.010. 


\title{
Emergence, transition, and continuity: Resource commodity production pathways in northeastern British Columbia, Canada
}

\author{
Abstract \\ The purpose of this paper is to reflect upon the processes of emergence, transition, and continuity \\ in global economic geography for one rural, and relatively remote, region in northeastern British \\ Columbia (BC), Canada. Guided by a theoretical framework comprised of staples theory, \\ evolutionary economic geography, and institutionalism, we reflect back on the path of the \\ resource sector and identify recent trends that are fundamentally reshaping the economic \\ geography of the region and province. Many of these changes are similar, albeit guided by new \\ technical and managerial processes, to historical patterns of resource exploitation that defined the \\ provincial and Canadian economy. Issues of dependence, vulnerability, and truncated regional \\ development would resonate with readers in the 1970s. Other issues, like the geographic \\ orientation of capital and the scale and rapidity of resource fluctuations bring new challenges to \\ local and provincial actors seeking to mitigate impacts and retain a greater share of benefits from \\ resource developments. The reflective synergy between emergence, transition, and continuity \\ seen in the case study is also noted in the theoretical framework as evolutionary economic \\ geography and institutionalism not only link to one another but also help to inform some of the \\ ideas at the core of staples theory. The paper contributes to an international discourse that is \\ seeking to document and compare cases associated with the new rural regional economies \\ emerging out of the rapid and far-reaching transformations of the global economy.
}

Key words: rural, staples theory, evolutionary economic geography, institutionalism. 


\section{Emergence, transition, and continuity: Resource commodity production pathways in northeastern British Columbia, Canada}

"Meet the new boss, same as the old boss..."

Peter Townshend, The Who, Won't get fooled again, 1971

\section{Introduction}

The global economic geography dynamic of the early 21 st Century is marked by emergence and transition. It may also be marked by continuity, and nuance within that continuity. Emergence, transition, and continuity are terms in the new regional economy discourse that we use as conceptual levers for understanding the dynamics of, and interplay between, global economic forces and local contexts. For continuity, we are referring to a continuation of basic relationships, policies, or processes associated with the old rural economy that has reinforced the production of low-value products found in staples economy regions in Canada, Australia, the US and beyond (Apedaile 2004; Argent 2013; Streek and Thelen 2005). Transition refers to a significant shift in established patterns that leaves the fundamental actors and processes changed but largely intact. In this context, rural economies have been reshaped by the adoption of labour-shedding specialized technology and infrastructure, the vertical and horizontal integration of firms, and by government policies and corporate strategies that have shifted from promoting local benefits to supporting the competitiveness of larger, international firms (Edenhoffer and Hayter 2013a; Irwin et al. 2010). For emergence, we are speaking of new dynamics, or the orientation of processes, that are re-shaping the regional landscape. This new rural economy is being transformed by new relationships, policies, innovations, and institutional arrangements that are supporting new markets and economic sectors for rural regions (Potts 2010; Ryser and Halseth 2010; Smyth et al. 2004; Uyarra 2010). The purpose of this paper is to explore the impacts and implications associated with these processes for one rural, and relatively remote, region in northeastern British Columbia (BC), Canada.

Long a resource commodity producing region, northeastern $\mathrm{BC}$ has economic activity in forestry, agriculture, and tourism. Through the latter half of the $20^{\text {th }}$ Century, however, its economic vitality was increasingly drawn from the energy sector. With a focus upon that energy sector, this 
paper opens with a discussion of three theoretical frameworks useful for evaluating the impacts and implications of emergence, transition, and continuity for a regional economy: "staples theory", "evolutionary economic geography", and "institutionalism”. As Martin $(2012,181)$ observes, rather than arguing about how one theoretical approach may or may not be superior to another, "it is far more constructive to see what each can learn from the other." Following the presentation of each theory, we outline a series of questions to help guide the inquiry and discussion for the paper. These theoretical sections are followed by a brief review of northeastern BC's energy sector history. Then, with a focus on coal and natural gas production, the paper examines the question of emergence, transition, and continuity in northeastern BC through the lens of these three frameworks. We hope to contribute to an expanding discourse on the relevance and meaning of new rural regional economies. The discourse on regionalism has tended to favour the economic regions of cities, but the previously "marginalized rural" (in research and theorizing) has again moved to the centre as it is increasingly bound to the epicentres of global economic expansion through the international commodity demands from a new set of rapidly industrialising powers.

\section{BC as a Staples Economy}

Through the $19^{\text {th }}$ and $20^{\text {th }}$ centuries, the export economy, development history, and nonmetropolitan settlement pattern of BC was organized around the principles of a staples-based economy. After World War II, the provincial government, under the leadership of W.A.C Bennett, implemented a more intensive industrial resource development model (Markey et al. 2012; Williston and Keller 1997). During this period, resource commodity production in BC came to mirror the scope and scale of industrial productivity that was emerging in the United States, Europe, and Japan.

\section{Staples Theory}

Staples theory provides a foundation for understanding the roots of long-term extraction of natural resource communities in a Canadian context (Barnes et al. 2001); although, it has also been applied to understand extraction driven economies in other countries, such as Australia, 
New Zealand, and Chile (Russi et al. 2008; Taylor et al. 2011; Tonts et al. 2013). Harold Innis was the first to describe the political economy of Canada as being organized around the notion of exporting minimally processed raw materials to more advanced industrial economies. $\mathrm{He}$ emphasized the concept of "staples" to describe these raw material inputs and went on to illustrate how the Canadian economy had developed over time through a succession of resources: fur, fish, gold, forest products, minerals, energy, etc. (Innis 1950). Relative to global trade, "Canada's historic position has been one on the margin of the leading sites of global industrialism and innovation" (Haley 2011, 99).

For Innis (1933), staples theory helps to describe the social, political, and economic implications of Canadian resource development. More specifically, staples theory describes patterns of uneven development and the peripheral role Canada assumed within the global economy (Weaver and Gunton 1982; Reed 2003). Innis posited that Canadian economic development centred around the extraction and export of minimally processed natural resources for the benefit of foreign metropoles (Hayter 2000; Marchak 1983). While other economic theories predicted that staples extraction would propel the economy towards maturation through the development of higher-order industries and interdependence, Innis countered that diversification and maturity were neither automatic nor assured (Marchak 1983). Indeed, Innis's staples theory has been labeled pessimistic because he saw the institutional framework associated with staples production as posing long-term barriers to development (Drache 1991).

For Innis, a dependence upon staples reinforces a "centre-margin relationship [that] generates a series of self-reinforcing rigidities" (Haley 2011, 100). The rigidities first set in place a sociotechnological system to support the export of staples, a system that needs attention when crisis disrupts the staples market. As Haley $(2011,102)$ states, "When crisis and change disrupt the old centre-margin relationship, the margin most eagerly seeks new connections with a centre to solve its internal problems. It must fill the unused capacity, pay off debts, and assuage its vested interests. It exploits more staples, often the different types of staples that the centres of the global economy demand, to enable new phases of growth ... [in other words] ...The staples trap describes the circular pattern behind Canada's historic tendency towards resource lock-in and truncated technological development". 
Through staples theory, the economic history and geography of Canada is viewed as being shaped by the export of natural resources to meet the needs of continental and international markets. Given the abundance of natural resources, it is not surprising that national and provincial governments have long based economic development strategies on resource exports. Within the context of Canadian staples industry, however, instability is entrenched (Barnes and Hayter 1994, 1997; Barnes et al. 2001; Hak 2007; Nelsen et al. 2010). Scholars interested in staples theory have built on the work of Innis to elucidate the problems that come from such an economic orientation (Hayter 1993; Barnes 1996a, 1996b; Davis and Hutton 1989; Watkins 1981, 1982). Two key problems that flow from a staples-based economy include "dependency" and "truncated development".

The dependency problem comes from the resource supply "warehouse" orientation of the regional economy. As "price-takers", producing regions are dependent upon the demands of external markets. As economically and industrially advanced regions expand or curtail industrial production, there are immediate impacts felt in the raw material supply chain. As Barnes (1996a, 216) notes, most staples regions "tend to be vulnerable to demand shifts in markets that are both highly competitive and price-elastic". Staples economies are dependent upon, and thus vulnerable to, market shifts. Over time, the fluctuations in global commodity demand have become more dramatic - rising faster than previously experienced, going higher than previously experienced, and contracting at similar "hyper" speed.

The dependence problem is exacerbated by the challenge of truncated development. World scale resource development projects require world scale firms and access to requisite levels of financing. Since the end of World War II, the provincial public policy approach in BC has been focused on attracting large industrial capital to realize the potential for massive resource industry development projects (Williston and Keller 1997; Marchak 1983; Mitchell 1983). Once in place, the region's resource commodity production path becomes increasingly entrenched as industrial capital consolidates its control over a stable and predictable supply of raw resources, its managing role on other components of the needed service and supply chain, and its dominance of labour by being the "only game in town". 
As Hayter $(1982,281)$ argued, the implication of such foreign ownership "relates to a loss of autonomy over strategic investments and technology decisions" (see also Haley 2011). Halseth and Sullivan $(2002,258)$ expand upon this idea, arguing that, "foreign controlled firms are often content to continue exporting basic resource commodities that are needed in their home economies or for other components of their multi-national holdings". One key effect of truncated development is that the long held mantra in resource producing regions about the need to diversify within existing sectors, across existing sectors, and to add whole new sectors, is nullified by the dominant industry's requirement to remain the regionally dominant industry. Research in Australia and the US suggests that long-term shifts to slowly transform a dependent region into a diversified region are trumped by "crises" within the dominant industry that threaten massive layoffs of labour and loss of tax and royalty revenues unless assistance and concessions are granted (Wilson 2004; Argent 2002). The "too big to fail" ethos has applied for decades in the industrial resource development version of staples economies (Hamilton 1999; Marchak 1983).

From dependency and truncated development, the questions relevant to this paper from staples theory include: 1) whether large industrial interests are investing in resource commodity projects, 2) whether, and how, this might be shifting over time, and 3) are there changes in local benefits (i.e.: jobs) within the producing region?

\section{Evolutionary Economic Geography}

With some focus upon the construct of "regional path dependence", the literature and debate within evolutionary economic geography can offer a different yet aligned framework to staples theory. Most especially, recent discussion around Martin's (2010) call for a "rethinking of path dependency in economic geography that underscores the importance of change" (Simandan 2012 , 156) provides a counterpoint to staples dependence and a set of tools for evaluating whether transformation in the regional economy of northeastern $\mathrm{BC}$ is one of emergence, transition, or continuity. 
For Boschma and Frenken (2006, 277), “Evolutionary Economic Geography applies core concepts and methodologies from evolutionary economics in the context of economic geography." Starting with the view that systems are sets of embedded routines; routines in firms, routines in policy, and routines in practice in institutions, evolutionary economic geography turns then to the issues of change and innovation. As befits its connections to geography, there is a concern with the spatial distribution of routines, and changes in these routines. As Martin (2012, 180) has argued, "any convincing theory of regional development needs to give explicit recognition to, and account for, the roles of history and path dependent dynamics and outcomes." But rather than viewing path dependence as inevitably supporting "locked-in" regional economies, he further argues that there must be room to admit other "more incremental and developmental patterns of evolution" (Martin 2012, 183).

But how do changes occur within path dependence? Are they slowly evolving, are they sudden, are their sources internal or external? These questions are the subject of much debate (Oosterlynck 2012; Drahokoupil 2012). Writing from a purely economic perspective, Bowles (2013) has noted how the northern BC resource commodity economy had adjusted through at least three phases - each with quite distinct policies and consequences. He notes that at present, northern $\mathrm{BC}$ is "experiencing new globalizing patterns as trade and investment flows and economic structures adapt ... [to the rise of the Asian economies, and] ... is actively seeking to reposition itself within the multi-centred global economy" (Bowles, 2013, 261). Similar trends have been observed in the Pilbara region of Australia which has become increasingly oriented and connected with Northeast Asian flows of capital (Sheppard 2013). We agree with the observation and similarly support the approach described by Martin $(2012,184)$ in that his proposed model:

Certainly does not exclude such shifts in trajectory, nor is it inconsistent with them. It was, rather, an attempt to argue that 'normal' path dependence can be seen more as a Schumpeterian process (Hayter 2008) of incremental mutation, rather than one of lockedin status. This is no way precludes the importance of the periodic creation of entirely new paths of industries, technologies, local clusters, regional economic trajectories, etc.. 
As with staples theory, evolutionary economic geography understands that social-politicaltechnological arrangements become established, and then embed these arrangements around temporally bounded regional economies. These include inter-firm competition, support and supply chains, labour arrangements, knowledge and technical production, etc.. Also with staples theory, change over time is both expected, and expected to be circumscribed by past economies and dependencies. For evolutionary economic geography, time and history are central players in the regional development story (Edenhoffer and Hayter 2013b). The argument in this case is that:

The current state of affairs cannot be derived from current conditions only, since the current state of affairs has emerged from, and has been constrained by, previous states of affairs. Evolutionary theory deals with path dependent processes, in which previous events affect the probability of future events to occur (italics in original) (Boschma and Frenken 2006, 280-281).

This attention to context fits, for example, with our broader interest in how place-based approaches to regional development can assist in understanding the nature of transformation (Markey et al. 2012).

From path dependency to processes of change, relevant questions for our research drawn from evolutionary economic geography include: 1) whether change from the previous regional development path is occurring, 2) whether any change is incremental or dramatic, and 3) are the changes apparent within the economic activity of the institutions (firms, policies)?

\section{Institutionalism and Environmental Economic Geography}

The third theoretical framework we introduce to support our analysis of emergence, transition, and continuity in the northeastern $\mathrm{BC}$ regional economy is environmental economic geography. Drawing upon Hayter (2008), environmental economic geography has its roots in an institutional perspective on "techno-economic paradigms". In this section, we describe first the institutional approach to economic geography, and then the more recent environmental economic geography. 
Each contributes to the analysis by helping focus attention on the roles of firms and against the emergent environmental concerns within policy and practice.

With a long theoretical pedigree that reaches back to the $19^{\text {th }}$ century and the work of Thorstein Veblen, institutionalism has emerged as a counterpoint to a Marxist analysis of the capitalist economic system. Instead of following the generalized, and perhaps totalizing, imperatives of capital and the labour-capital dynamic,

Evolutionary institutionalism rejects the idea of a universal model of capitalism and describes its generalizations and prescriptions from close observation, measurement and interpretation of real-world institutions that are variously expressed as formal and informal organizations, movements, common values ... an insistent theme for evolutionary institutionalism is the power of big business to shape the nature of market economies, rather than simply passively responding to consumer sovereignty and government regulations (Hayter 2008, 834).

For our purposes, the institutional approach reinforces the need to identify the international capital players, in the form of multi-national firms, in the economic restructuring of northeastern BC.

Institutional economics is described as a "third way" or "middle-range" approach to the economy (Hudson 2006; Peck 2000). Prior to the economic restructuring of the 1980s, economic geographers commonly approached the economy using either neoclassical or Marxist theory (Cumbers et al. 2003). The neoclassical approach assumed that economic activity is rational, maximizing, and atomistic, while ignoring complex arrangements of social and political forces, space, and people at work (Leyshon 2011; Martin 2000). By comparison, other researchers have suggested that Marxist approaches emphasized the importance of social structures while placing little emphasis on individual and collective agency, or the role of culture (Cumbers et al. 2003; Hudson 2006). Both approaches are under-contextualized in that the peculiarities of places and society are not addressed (Martin 1994). The institutional approach gained favour within economic geography, and other social sciences, because it accounts for the social and cultural 
conditions of everyday life and real world behaviours (Hayter 2004). Institutionalists have focused on how past and present arrangements of individuals, institutions, cultures, and politics in different places work to shape economic development (Barnes and Gertler 1999; Peet 2007).

Institutions are socially constructed and include formal regulations and informal practices, routines, and habits that shape the behavior of actors. Formal regulation includes laws, policies, standards, and rules. Informal or tacit practices can include local networks, habits, norms, routine patterns of behavior, and customs (Nee 2005; Streek and Thelen 2005; Swedburg and Granovetter 1992). As such, the make-up and mix of informal and formal institutions are rooted within place, and tend to vary across space (Boschma and Martin 2010; Hayter 2004). The strength of this approach for studying regional economies is that it takes a broad view of economic activity, where different actors (firms, governments, organizations, individuals, etc.) cannot be divorced from local culture, history, or society (MacLeod 2001).

Through this theoretical lens, regions take on a new prominence as meeting places for a variety of global and local institutions and the conflicts, relations, and discourses that shape, constrain, or transform the economy, society, and culture (Amin 1998; Paasi 2009). This conceptualization is grounded firmly in the notion that regions are not fixed, concrete, or predetermined entities (Lee 2002). Rather British, American, and Finnish researchers suggest that regional economies are perpetually fluid due to the changing nature of resources, markets, technology, policy, and relationships over time (Paasi 2002; Essletzbichler and Rigby 2007). This is an important distinction because it raises the role of space, scale, and time in shaping the particularities of different regional economies (Page 1996). Variation across regions is expected, and the development of regional economies will follow a trajectory of change shaped, in part, by the history of past decisions (Peck 2005; Swedberg and Granovetter 1992). The new institutions are built, or layered, upon existing institutional arrangements.

The "evolutionary" aspect of evolutionary institutionalism links to the concept of change (like with evolutionary economic geography). It makes this link through the analysis of innovation. For Hayter $(2008,831)$, evolutionary institutionalism "interprets industrial transitions through the lens of innovative behavior that is shaped by reciprocal economic and non-economic 
processes and periodically restructures economies in the form of new techno-economic paradigms (TEP)". The concept of innovation provides a "central, unifying theme that coevolves as institutional and technological dimensions according to changes that are incremental, major, radical and paradigmatic" (Hayter 2008, 832).

Innovation and evolution also link to the evolutionary economic geography framework. As Boschma and Frenken $(2006,289)$ point out, within "an evolutionary framework, the key issue is to analyze the extent to which institutions are flexible and responsive to changes in different places ... [and how] ... institutions co-evolve with processes of technological innovation and industrial dynamics." This role for innovation also connects with our concern with assessing the economic transformation of northeastern BC in terms of emergence, transition, or continuity. Just as staples theory understands that resource commodity economies will emerge from, and will co-create, unique combinations of technology, policy, and social constructs to support the particular mode of production, so too does the evolutionary institutionalism approach recognize the temporal and geographic collisions that create unique TEP's. In our assessment, we also agree with a need to assess and make clear the roles of policy and technology to support particular economic transitions.

Hayter then connects institutionalism and evolutionary institutionalism with emergent environmental concerns. Describing the socio-political embeddedness of firms, he writes,

Social institutions, entitlements and liabilities of firms (and other institutions) are changed by policy and/or reformulation of attitudes. In practice, the environmental policies of government across all market economies have escalated over the past 50 years to redefine property rights in terms of environmental responsibilities and to increasingly internalize environmental costs (Hayter 2008, 835).

This then provides an approach that adds to our evaluation of economic transformation in northeastern BC's regional economy. The question is whether environmental concerns are becoming an increasingly important aspect of development policy and regulation, and by extension, whether emergent First Nations and northern community concerns are similarly 
gaining relevance. For this, we look to provincial government policy statements as to any "corrections" in the balance between economics, the environment, community, and state interests and needs.

From institutional and environmental economic geography, questions that emerge for our inquiry include: 1) who are the economic institutional actors within the regional economy, 2) how are changes in the regional economy nested within the context of place, and 3) is there evidence of a shift in emphasis from the economic to the environmental (and community)?

\section{Northeast BC's Energy Economy}

Northeastern BC's energy economy is predicated on the accidents of geology. The region lies between the Rocky Mountains and the provincial border with Alberta. This "prairie" landscape is a product of a vast inland sea that covered much of what is now the interior of North America. The collisions of plate tectonics that pushed up the Rocky Mountains also added pressure to the deep organic sediments of that ancient sea to produce the region's rich coal, oil, and natural gas deposits.

The region is $117,761 \mathrm{sq} \mathrm{km}$ in size and is home to 65,660 people (Statistics Canada 2011). The main population centres of the region are Fort St. John $(18,609)$ and Dawson Creek $(11,583)$, which are surrounded by a series of smaller rural settlements, including Chetwynd, Hudson's Hope, Pouce Coupe, Taylor, and Tumbler Ridge. Aboriginal peoples represent $13 \%$ of the regional population (compared with a provincial average of 5\%), in five Aboriginal communities: Blueberry River First Nation, Doig River First Nation, Halfway River First Nation, Moberly Lake West First Nation, and Saulteau First Nation. These Nations have formed the Treaty 8 Tribal Association with a mandate to act as a coordinator, a facilitator, and to provide technical support on various issues as mandated by the Council of Treaty 8 Tribal Association Chiefs.

With a relatively limited secondary economy, most of the economic activity in the communities revolves around the resource sectors. A large share of the workforce is employed either directly 
within resource production or in one of the service activities that support the production. Even those in other sectors; retail, education, corrections services, healthcare, etc., owe much of their employment to the households working in the resource sector. As Halseth and Sullivan (2002, 91) note "the day to day lives of workers and their families revolve around the shift schedules of the mills or mines. The annual cycle of activities and events in the town revolve around the annual production, maintenance, and shutdown periods for these dominant employers." These are places defined by work; and work is often defined by clearly demarcated gender roles (Reed 2003).

Oil and gas exploration in northeastern BC's Peace River region began in the $1920 \mathrm{~s}^{1}$. However, it was after the completion of the Alaska Highway in 1942 that oil and natural gas exploration began in earnest. Natural gas production became commercially viable in 1948, and the first refinery in the region opened in 1955. In the same year, Westcoast Transmission Company completed its gas mainline to southern BC, and in 1957 Westcoast began the first natural gas exports to the United States via its pipeline crossing near Vancouver. By the end of the 1990s, over half of BC's natural gas production was exported to the US (Ostergaard, 2002). Energy exploration soon expanded across the entire region, extending into the northern Fort Nelson area by 1958 .

Northeastern BC's oil and gas activity underwent rapid growth in the early 1990s. Its spatial orientation was, and is, continental. Oil production has a limited number of pipelines that run south into the province. There is one line to Prince George to service a small refinery, the products of which are used almost entirely within the central interior's pulp and paper industrial complex. There is also a larger line that runs south to Vancouver where another refinery processes the oil for export by tanker. Most of the rest of the oil production flows into the North American distribution system. The flow is first east into Alberta, where it joins the major pipeline systems running south into the United States.

More recently, however, the oil and gas sector across the Peace River region has undergone a series of fluctuations. In 2000, Westcoast Energy announced the closure of the Aitken Creek

\footnotetext{
${ }^{1}$ Information for this historical timeline was provided by the BC Oil and Gas Commission.
} 
natural gas processing plants near Fort St. John (Prince George Citizen, 2000). Williams Energy Services (US based) made several major acquisitions in the Peace River region late in 2000, but quickly sold its natural gas processing and liquid extraction operations shortly thereafter in 2002 (Heintzman 2002). Following the subprime crisis in the U.S. in 2007, there was a slowdown in the economy, including in the forestry, mining, and oil and gas industry that affected contractors and suppliers (BC Government, 2010; Holloway, 2008). Proposed developments had been delayed as companies re-examined their business plans or failed to obtain adequate investment capital from tightening global capital markets. At the same time, however, there was a series of announcements for new pipeline construction projects (Alaska Highway News, 2007). The Horn River Basin Producers Group was also formed in 2007 to facilitate cooperation between the oil and gas industry, First Nations, and government stakeholders on technical, economic, social, and other related issues. Since 2008, there have been a number of announcements related to the selling and purchase of properties and subsurface mineral rights in the northeast region (Gousseau 2008; Holloway 2008; Prince George Citizen 2009). Today, there are numerous oil and gas related projects being initiated by companies such as Encana, Spectra, Shell, and Talisman Energy.

\section{Coal Production}

Coal mining in northeastern BC had developed around the towns of Chetwynd and Tumbler Ridge. Both towns are in the eastern foothills of the Rocky Mountains, and their coal deposits come from that ancient ocean bottom now thrust closer to the surface with the rise of the mountain chain. Regional coal resources have long been known, but in the mid-1970s world prices and demand prompted a flurry of formal exploration. More than 15 coal claims by a variety of multi-national and national firms were staked in the region. Companies included BP Exploration Canada (1979), Cinnabar Peak Mines (1981), Denison Mines (1982), Pacific 66 (1978), Petro Canada (n.d.), Teck Corporation (1981), Utah Mines (1976). Out of this resource scramble, two mines got underway in the early 1980s. Denison Mines Ltd. developed the Quintette mine (1,500 employees) through its subsidiary Quintette Operating Corporation, while Teck developed the Bullmoose mine (500 employees) through its subsidiary Bullmoose Operating Corporation. Ownership of the Bullmoose mine was divided between Teck (61\%), 
Reo Algom Limited (29\%), and Nissho-Iwai Limited (10\%) (http://www.teckcorp.ca/, 7 july2000).

While Chetwynd is an older community, one built around a forest industry base, construction of the Tumbler Ridge town site began in 1981. The first shipment of coal to the Ridley Island port was sent by rail in 1983. Global commodity prices and corporate restructuring affected Tumbler Ridge from its opening. The economic viability of its original mines, especially the larger Quintette mine, was put in question almost as soon as it opened as a result of a pricing conflict with the Japanese steel mills that were purchasing the coal. The Quintette mine closed in 2000, and the smaller Bullmoose mine closed in 2003.

The critical challenge for staples economies in an increasingly globalized world is two-fold. On the one hand, a large multi-national company can more effectively and efficiently market products and take advantage of its global trading networks and partnerships. On the other hand, such multi-national firms owe allegiance to shareholders and not to towns. As Halseth and Sullivan $(2002,98)$ note:

If a particular plant of resource is no longer profitable, a company will be under shareholder pressure to close it down. While companies can shift their capital around the world relatively easily, towns - and the people who create lives and communities there are not so mobile and closures can have traumatic impacts.

As noted in Table 1a, the early expressions of interest in coal mining through northeastern BC largely involved companies from Canada. There were also expressions of interest from two United States-based firms and one British-based firm. However, once the mines moved into active development and production, the ownership was dominated by Canadian mining companies. Denison Mines had a 100\% ownership share of the Quintette mine, and Teck Corporation as well as Rio Algom Limited had a combined 90\% ownership stake in the smaller Bullmoose mine. 
Since that time, however, the ownership structure of coal mining has changed considerably (Table 1b). In the early 2010s, there were four coal mines operating in the Chetwynd and Tumbler Ridge area. Three of these were owned by Walter Energy, which is based in the United States. The other was owned by Anglo-American, which has its head offices in Britain.

In addition, there are several significant proposed mines in the area. Almost all of these are proposed by those firms already active in the area (Walter Energy and Anglo-American), including one joint venture between the two firms. However, the most extensive new proposal is from a China-based firm HD Mining International Limited. HD is proposing an underground mine that would operate with approximately 600 workers.

\section{Natural Gas}

The new "rush" in northeastern BC is around natural gas. Specifically, it is organized around the desire of companies to ship large volumes of natural gas overseas through the process of liquefied natural gas export. This has been spurred by the BC provincial government's renovated natural resource development policy that is based around the export of massive quantities of liquefied natural gas (LNG) (Ministry of Energy and Mines 2013a, 2013b). The target markets for this export are the expanding Asian economies. The suggested rationale for the LNG sales is to meet the energy needs of those economies. These energy needs are arising not just because of expanding industrial development, but also the desire of some states to move away from nuclear power and the desire of others to substitute cleaner burning natural gas for their current reliance upon coal fired electrical generation.

The provincial government policy builds upon an earlier period of provincial revenues through the sales of exploration and leasing rights to natural gas regions across northeastern BC. Plummer and Tonts (2013) describe a similar "boom" in resource development across rural and remote regions of Australia that form the core of a re-emergence of staples driven national and state development policy. Much of this "boom" in new natural gas leases was spurred by the development of "fracking" technologies that would allow natural gas currently trapped in shale and other geologic formations to be loosened from the substrate and captured for export. This is 
a controversial practice, but one which is becoming more common across natural gas production regions in North America (Brasier et al. 2011; Schafft et al. 2013).

To realize the export potential of this new volume of natural gas, the provincial government has been encouraging proponents to develop LNG export terminals and pipelines (Ministry of Energy and Mines 2013a, 2013b). The pipelines follow several corridors from northeastern BC to the Pacific Ocean on the northwest coast. Most (but not all) of the LNG terminal proposals are centred either around the port facilities of Kitimat or Prince Rupert.

When we look at the proposals described in Table 2, we note that similar to Tables 1a and 1b, there has been a notable switch to international capital. The massive investment cost for LNG terminals and new pipelines requires significant access to capital. In addition to international ownership, many of the proposals are consortium arrangements between numbers of major international energy companies. There are currently four proposals for LNG terminals in Kitimat. These include LNG Canada, Kitimat LNG, the Douglas Channel LNG, and the Triton LNG projects. Significant international participation from the United States is noted in two of those proposals, while the other two involve both Asian and European headquartered partners. There are currently two LNG terminal proposals for the Prince Rupert area. The first is the Prince Rupert LNG project which includes a partnership between United States and British based companies. The second is Pacific Northwest LNG which is a wholly owned proposal by Malaysian-based PETRONAS.

In 2013, the provincial government identified a new terminal location for an LNG export plant in the Prince Rupert area and asked for expressions of interest. As shown in Table 2, four proposals have been brought forward. The first is a consortium of Asia-based companies including significant participation from CNOOC in China. The second is a wholly owned proposal from Australia, while the third is a similarly wholly owned proposal from Korea. The fourth proposal was a joint undertaking between two traditional energy firms based in the United States.

\section{Discussion}


The new regional economy of one staples producing region both resembles and departs from its older self. These resemblances and departures arise from the continuing role of resourceproducing peripheries and suppliers of raw materials to global manufacturing cores and the geographic shift in the global manufacturing core from the United States to Asia. In this section, we review the questions posed in our literature review and then outline points of resemblance and departure as found in northeastern BC's energy sector.

\section{Questions}

When we look at the questions raised through staples theory, we can identify that indeed large industrial interests are continuing to "buy-in" to northeastern BC's energy sector. Relative shifts over time have included the replacement of Canadian firms with international firms, and by an increasing participation by Asian-based investment. When it comes to questions of local benefits, mining industry benefits continue to be focused upon local employment. There is certainly significant local employment and this includes First Nations in the region. However, the HD mine proposal in Tumbler Ridge raised national controversy over plans to include large numbers of temporary foreign workers during the mines development phase (Yaffe 2013).

For the LNG plants, there is much more attention being paid to local benefits. In addition to employment, a number of companies have signed partnership agreements with local and regional First Nations communities. In part, this is spurred by the lack of treaty arrangements in British Columbia and the need to consult and accommodate First Nations' interests. In one case, we see that the Douglas Channel LNG project has a specific partnership arrangement with the Haisla Nation (Province of British Columbia 2012). Similarly, the Kitimat LNG project, through the Pacific Trails Pipelines Limited Partnership Agreement, expects to share up to $\$ 200$ million in financial benefits with regional First Nations communities along the pipeline route over the life of the project. In February 2013, 15 First Nations had signed on to take part in the partnership agreement (Apache Corporation and Chevron Canada 2013).

The details of these agreements concern contracts, jobs, training, land, and financial contributions to support services and infrastructure investments in these First Nations 
communities. Similar trends are taking place in other resource regions around the world, such as Australia, where, as Cheshire (2010) argues, Aboriginal communities are becoming increasingly influential to regulate access to resource assets through Native Title Agreements. In this context, many Aboriginal, as well as non-Aboriginal, communities have benefitted from mechanisms such as social licenses that have resulted in the development of community foundations, as well as other contributions to support services, events, training, housing, and the preservation of cultural and environmental assets. O'Faircheallaigh (2013) further suggests that a new political landscape is emerging that is producing a shift in power relations and distribution of costs and benefits stemming from resource activities to Aboriginal communities.

But challenges remain around Aboriginal participation. For example, the Gulf Communities Agreement between four Native Title Groups, a major mining company developing, and the State of Queensland describes various roles and responsibilities around land use and benefitsharing. Fifteen years after it was signed, Everingham et al. (2013) found that while there were successes around the extension of employment and training, development of Indigenous enterprises, cultural heritage management, improved communications infrastructure and services, and access for the ongoing monitoring of environmental impacts, there were still concerns about uneven development and persistent socio-economic disadvantage.

Questions arising from evolutionary economic geography lead us to identify that indeed changes are occurring in the energy sector across northeastern BC. In addition to changes in the ownership structure, we are seeing changes in emphasis as natural gas comes to play a more prominent role. These changes appear to be both incremental (in terms of the shifts in ownership structure and operating scale of coal mining) as well as dramatic (as in the case of natural gas activity increasing dramatically through the advent of LNG export opportunities).

In terms of the questions posed by environmental economic geography, we can certainly identify that international capital players are involved and have largely replaced Canadian firms. These are significant institutional issues as the shift in negotiations and norms of operating behavior are brought with those different institutional players. Second, there does appear to be a good fit with the pre-existing context of place. The previous set of institutions and policies to support the 
export of large volumes of energy resources continues. The massive growth in new LNG project proponents fits nicely into this pre-existing regional institutional framework.

With respect to changing awareness around environmental issues, the Canadian legislation for environmental protection is relatively weak (Boyd 2003), but offers mixed results by sector. For operating coal mines, their footprints are generally quite limited and the requirements for environmental monitoring and site remediation have been practiced for decades. In the case of LNG, there is more debate. Concerns about fracking practices, and the vast area over which fracking activity would take place is one area of concern. However, the documents being submitted by various LNG proponents clearly identify areas of environmental concern and a recognition on their part for addressing both environmental and community concerns before moving forward with the projects. It appears that there is increasing recognition across this new energy sector of the need to incorporate both economic and environmental issues in project evaluation. The increasing demands for and awareness of a social license to operate are shifting the terms and conditions of project development (Yakovleva 2005, Michell and McManus 2013, Owen 2013).

At a more general level, points of similarity and resemblance to older regional economy geographies of rural resource producing areas are many. To start, the region is still mired in a staples economy. It continues to focus on the production of low value raw materials as industrial inputs for more advanced economies outside the region and hemisphere. Despite calls for diversification, the region, (and the province by extension) continues along a development path characterized by a narrow range of products, the demand and price for which are subject to wide fluctuations. A preview of the LNG future in BC may be seen in the story of the Tumbler Ridge coal mines. Originally opened in response to a growing demand for metallurgical coal by the Japanese steel industry (and a resulting high global commodity price), the increasing participation of new coal producing regions around the Pacific rim soon met that demand and drove prices down dramatically. This would lead to near bankruptcy and eventual early closure of the Quintette Mine in the Tumbler Ridge area. 
The second feature of similarity and resemblance comes from the region's continuing dependence on large industrial capital to undertake new projects. As a result, these new projects require global economic players building and managing their development, construction, and operations. This is likely to perpetuate the truncated development aspects of the region's staple economy as seen in past iterations. The substitution of capital for labour in BC's traditional resource producing regions now means that less employment and fewer local benefits are following from raw materials processing (Edenhoffer and Hayter 2013b; Markey et al. 2012; Hutton 2002; Halseth et al. 2004; see also Mackenzie and Norcliffe 1997). Tonts et al. (2013) provide a contemporary Australian example of how resource producing regions also continue to reap limited benefits from resource production. They argue that "as with the nation's previous resource booms, there were marginal transformations in the economies of those regions from which the minerals were extracted. Overwhelmingly, the wealth generated by the resource boom has concentrated in the cities" (Tonts et al. 2013, p. 365). They go on to argue how the recent resource boom in Australia simply reproduces the staples trap of a region where the "development framework [is] oriented towards extraction rather than diversification" (Tonts et al. 2013, p. 365).

Issues of truncated development link to another long standing aspect of staples theory: dependence. While the "geography" has shifted, the dependence on external markets and the increasing competition from other (especially low cost) raw commodity supply regions all suggest that exaggerated boom and bust cycles are a feature of the new economic geography of the region. Worse, in order to remain competitive in low value added raw resource commodities, there have been many efforts at cost reductions by capital. Job reductions and outsourcing of services have left fewer benefits regionally, and calls for government to assist price/profit points by reducing regulatory burdens, etc., all suggest that over the communing decades there will be an increased "race to the bottom" amongst industrial sectors.

Points of departure are also many. Some are more nuanced and others more dramatic. In terms of nuanced differences, there are several. The first, of course, is the shift in the locus of commodity markets. In general, the shift now underway is from continental North America and the US market, to Asia. The immense growth of the Chinese economy, coupled with strength in Korea, 
Japan, and elsewhere is "relocating" the markets for northeastern BC's energy and metallurgical coal commodities. This reorientation to new markets for old staples is what Sheppard (2013, p. 268) found in Australia where the "global positionality of Western Australia and the Pilbara has changed rapidly, increasingly oriented northward rather than eastward". He notes that, "as the Pilbara has become more interconnected with the now increasingly Northeast Asian core of globalizing capitalism, Western Australia has become increasingly resource oriented"' (2013, p. 265).

The second difference, hinted at above, is that northeastern BC's regional economy is also seeing variable benefits from staples resource activity. The region benefits from a regional oil and gas royalty fund, the Fair Share Agreement, that is administered by the Province on an annual basis (scheduled to expire in 2020) and distributes upwards of $\$ 28$ million to municipalities within the region. The substitution of technology for labour, and the flattening of management structures returns more profit directly to the companies and shareholders, and leaves less in the region. For example, the 1,500 people once needed in the Quintette mine are now replaced by 200 to 300 workers at current mines.

Some of the points of departure, however, may seem more dramatic over time. For example, the use of temporary foreign workers and the potential development of more fly-in / fly-out projects could significantly reduce the local and regional benefits of resource commodity production (Markey and Heisler 2011). There is the potential that these resource producing regions will realize very few benefits while bearing all of the long-term social and ecological cost of nonrenewable resource extraction.

As a counter, the increasing participation of regional First Nations in dialogue over development proposals may see more joint partnerships over impact/benefit agreements come into place. This would reverse some of the outward flow of benefits (in the form of employment and cash). The question remains, however, whether such cash payments can ever compensate or account for the impact of non-renewable resource extraction in traditional territories.

Theoretical collision 
In addition to the questions raised within each of the theoretical frameworks described above, the research also found considerable linkages and complimentarily between the core concepts of staples theory, evolutionary economic geography, and institutionalism. This collision of theory warrants a few observations, especially since one of the frameworks (evolutionary economic geography) has yet to be extensively deployed in the study of rural resource economies.

A first point of theoretical complementarity is with the concept of path dependence. Within staples theory the argument is that regional economies become "locked in" as the social, economic, labour, investment, institutional, and infrastructure elements of established resource economies drive thinking and decision making. As noted above, Innis saw the role of institutions as critical in reinforcing path dependence, regional development rigidities, and economic "lock in". The notion of lock in is also supported by the institutional aspects of evolutionary economic geography. Sheppard (2013, p. 271), for example, identifies these theoretical links through the notion of "connectivities: core-periphery relations, foreign investment and imported technology". Together these substantiate and make more rigid the particular techno-economic (and socialpolitical) paradigms of different development eras. The scope and scale, as well as the historical foundations supporting the trajectories of path dependence is described by Sheppard (2013, p. 272) through the example of Australia's Pilbara region, where:

Assemblage of capital-intensive extractive technologies, skilled labour, mining towns and labour camps, massive ore trains on dedicated rail lines, offshore drilling platforms, harbours, and ore and natural gas freighters also play a critical role. None of this would have been possible, however, without a legal structure that initially enabled land-based resources to be alienated from the Indigenous inhabitants, reflecting the racialised attitudes accompanying European settlement.

In our case study, path dependence within natural resource production remains strongly entrenched and supported by the region's, and the province's, prevailing staples paradigm. 
A second point then concerns explaining the potential for, or the possible pathways to, change within a staples dependent, path dependent, system or region. Within staples theory, Innis and others highlighted the role of "shock" as external markets shifted (often quickly and dramatically) away from a region's staple product. Both institutionalism and evolutionary economic geography add crucial support for incorporating adjustments and changes. Tonts et al. (2012, p. 292) reference the recent Australian experience with "adjustment, adaptation, restructuring, transformation, transition, and change" to see "how particular institutions, sectors, enterprises, localities, and regions have fared in the face of multi-scalar economic, social, and political processes". They employ the notions of path dependence and adaptation from evolutionary economic geography. Building from a significant literature review of Australian economic geography research, they argue that to understand the evolutionary aspects of evolutionary economic geography "more explicit attention needs to be paid to systematic understandings of the dynamics of change" (Tonts et al. 2012, p. 292). As with other writers within evolutionary economic geography, they then argue for the importance of both time and trajectories, as well as an "appreciation of how economic, social, and political processes operating across time interact in ways that are spatially connected and contingent" (Tonts et al. 2012, p. 296-297). Depth of historical trajectories also link to both understanding path dependence as well as adaptation and change. Again, for our case study the processes of change are both apparent but also highly circumscribed by path dependence.

However, understanding how regions or places respond to shock is at least as important as understanding that shock or crisis can redirect development trajectories within even the most rigid of staples producing systems. Adding theoretical depth around how places respond to, or adapt to, crisis and change means attention to the uniqueness of places and regions. Here, while each of staples theory, institutionalism, and evolutionary economic geography are "macro" frameworks concerned with general processes, their execution has often been around the creation and adaptation over time of "local models" of production. This is a third point of theoretical complementarity.

For Innis, local models were about the succession of resource dependencies that happen through time in hinterland areas. The potential to shift over time speaks to the importance of 
incorporating an understanding of the unique circumstances and assets of places. Tonts et al. (2012, p. 300) link the process aspects of the "evolutionary" elements within evolutionary economic geography with concepts like "place and path dependence to help understand the deep historical and spatial processes that lead to the creation of particular rural places as bundles of 'space/time"' (Tonts et al. 2012, p. 300). For Sheppard (2013, p. 266), it is the uniqueness of place and region, within the localized processes of time and trajectory, that creates "assemblages of connectivities [yielding] socio-spatial positionality". The adaptive element is conceived in his example from the Pilbara in how the region "as a place both reflects these shifts and cements them in place, a process Massey (1984) dubbed geological layering. Some features have massive durability, defining place, but nonetheless can dissipate as positionalities shift" (Sheppard 2013, p. 272). Local assets and global competitive forces, uniqueness within generalized economic systems, and the divergent needs and interests of localities, regions, and states all play roles in how assemblages and connectivities change and what might constrain the way they change over time.

There is a good deal of internal consistency across the three theoretical frameworks of staples theory, evolutionary economic geography, and institutionalism as used in this paper. As Canadian researchers, we have been interested in the ways evolutionary economic geography and institutionalism have enhanced the explanatory value of staples theory. As noted in this section, the notions of path dependence, change, and then the uniqueness of place within these general processes of dependence and change are central to the themes of emergence, transition, and continuity in our regional case study. The emergence of a new LNG opportunity and new target markets implies change and transition, yet at the same time it reinforces continuity in a more general path dependence upon staples production and the export of minimally processed raw materials for limited economic benefit to the resource producing regions relative to its final product value. Similarly, the emergence of a new LNG opportunity and markets is creating change and transition in the locus of economic capital behind industrial investment while maintaining continuity from staples theory on the reliance upon outside capital. To this point, the study of rural resource industry and community change has been marked by the application of singular theoretical frameworks (or at best a nod from one to another). By drawing together staples theory, evolutionary economic geography, and institutionalism, we argue that there is not 
only promise, but also much more value yet to be discovered, by applying these frameworks as a complementary analytical frame within this geographic context.

\section{Conclusion}

This paper has examined a suite of issues surrounding the emergence, transition, and continuity evident within northeastern British Columbia's regional economy. With a focus upon the energy sector, several trends within each of these conceptual levers are evident. Importantly, these trends can be seen at two levels: the macro-economic structure driving changes, as well as the local outcomes of those changes. In terms of continuity, the region is still dependent upon the export of limited manufactured raw resources into advanced manufacturing centres. It remains a price taker in the market and it still dependent upon investments by large firms with international connections. In terms of transition, there are several shifts in existing actors and processes. To start, the firms are larger and increasingly international. While the coal industry initially developed with significant Canadian corporate investment, the new LNG proposals all include global scale multinational players. While the markets for northeast coal resources were Japanese, there has been a significant transition in markets. Coal is shifting from a Japanese focus to a wide set of Asian markets. LNG will shift gas markets from their historic continental focus on to an Asian focus. A further transition has been the shift away from local jobs and local benefits to more emphasis placed upon corporate and shareholder profitability. In terms of emergence, several key points can be made. The first is that whole new markets for northeastern BC's energy sector are emerging. Principal among these are China, Korea, and several small Asian players. In addition, there has been an emergence of entire new economic sectors. Primarily, this includes the LNG proposals, which are taking the older natural gas industry into an entirely new direction at a new scale.

Northeastern BC is like many resource producing rural regions in developed economy states. Long outside the power of decision making structures of national and global economies, they have never the less been intimately bound-up in those national and global economies. To understand some of the possible shifts in the regional economic geographies, we have used staples theory, evolutionary economic geography, and institutionalism to pose questions about 
how one rural region may be reacting to the processes of emergence, transition, and continuity of global commodity markets in the early part of the $21^{\text {st }}$ century. Our investigation suggests that the "position" of resource commodity producing regions has not changed. The dependence, vulnerability, and truncated development experienced after World War II seems to be continuing. On the other hand, the relative stability of these regions experienced from 1950 to 1980, which was disrupted after that time, seems ever more elusive. Increasingly limited and variable local benefits, significant environmental impacts, and wide social and economic fluctuations associated with expansion and curtailment in the resource producing sector, seem the pattern going forward. Indeed, there may be even more pressure on benefits flows and wide fluctuations in an increasingly hyper-active global economy. The discourse on the new rural regional economies has much to contribute to understanding how to navigate these complex global-local dynamics. 


\section{Bibliography}

Alaska Highway News. 2007, March 2. Pipeline projects on the go. Alaska Highway News, p. A1.

Anglo American. 2013. Available at http://www.angloamerican.com/ Accessed April 23 ${ }^{\text {rd }}, 2013$.

Anglo American. 2012. Fact Book 2011/12. Anglo American Plc. Available at http://www.angloamerican.com/ /media/Files/A/Anglo-American-

Plc/media/fact_book/FACT_BOOK_FINAL_2012.pdf Accessed April 23rd, 2013.

Amin, A. 1998. An Institutionalist Perspective on Regional Economic Development. Paper presented at the Economic Geography Research Group Seminar on Institutions and Governance. Department of Geography UCL, London.

Apache Corporation. 2013a. Consistent Profitable Growth. 2012 Annual Report. Available at http://www.apachecorp.com/Resources/Upload/file/investors/Apache_AR_2012.pdf Accessed April $23^{\text {rd }}, 2013$.

Apache Corporation. 2013b. News Release. Apache, Chevron complete Chevron Canada's entry into Kitimat LNG. Houston, TX. February $11^{\text {th }}$. Available at

http://investor.apachecorp.com/releasedetail.cfm?ReleaseID=739349 Accessed April 23 ${ }^{\text {rd }}, 2013$.

Apache Corporation. 2012. News Release. Apache Canada, Chevron Canada announce joint venture for Kitimat LNG project. Houston, TX. December $24^{\text {th }}$. Available at http://investor.apachecorp.com/releasedetail.cfm?ReleaseID=728700 Accessed April 23 ${ }^{\text {rd }}, 2013$.

Apache Corporation, and Chevron Canada Ltd. 2013, February 25. News Release. Pacific Trail Pipelines Limited Partnership sign \$200 million commercial agreement with 15 First Nations regarding the pipeline component of the Kitimat LNG Project. Vancouver, BC.

Apedaile, P. 2004. The new rural economy. In: Halseth, G. and Halseth, R., Editors, Building for Success: Explorations of Rural Community and Rural Development, pp. 111-134. Rural Development Institute, Brandon University, Brandon, MB.

Argent, N. 2013. Reinterpreting core and periphery in Australia's mineral and energy resources boom: An Innisian perspective on the Pilbara. Australian Geographer 44 (3), 323-340.

Argent, N. 2002. From pillar to post? In search of the post-productivist countryside in Australia. Australian Geographer 33 (1), 97-114.

Barnes, T. 1996a. External shocks: Regional implications of an open staple economy. In: Britton, J., Editors, Canada and the Global Economy: The Geography of Structural and Technological Change, pp. 48-68. McGill Queen's University Press, Montreal. 
Barnes, T. 1996b. Logics of Dislocation: Models, Metaphors, and Meanings of Economic Space. Guilford Press, New York.

Barnes, T. and Gertler, M. (eds.) 1999. The New Industrial Geography: Regions, Regulation, and Institutions. Routledge, London.

Barnes, T. and Hayter, R. (Eds.) 1997. Troubles in the Rainforest: British Columbia's Forest Economy in Transition. Canadian Western Geographical Series 33. Western Geographical Press, Victoria, BC.

Barnes, T. and Hayter, R. 1994. Economic restructuring, local development and resource towns: Forest communities in coastal British Columbia. Canadian Journal of Regional Science 17 (3), 289-310.

Barnes, T., Hayter, R. and Hay, E. 2001. Stormy weather: Cyclones, Harold Innis, and Port Alberni, BC. Environment and Planning A 33 (12), 2127-2147.

BC Government. 2010. 2010 British Columbia Financial and Economic Review. Ministry of Finance, Province of British Columbia, Victoria, BC.

BC LNG Export Co-Operative LLC. 2011. Natural gas export license application. Made pursuant to Section 117 of the National Energy Board Act and regulations thereto. March $8^{\text {th }}$.

Binkley, C. 1997. A cross road in the forest: The path to a sustainable forest sector in British Columbia. In: Barnes, T. and Hayter, R., Editors, Troubles in the Rainforest: British Columbia's Forest Economy in Transition, pp. 15-35. Western Geographical Press, Victoria, BC.

Boschma, R. and Frenken, K. 2006. Why is economic geography not an evolutionary science? Toward an evolutionary economic geography. Journal of Economic Geography 6 (3), 272-302.

Boschma, R. and Martin, R. (eds). 2010. Handbook of Evolutionary Economic Geography. Cheltenham: Edward Elgar.

Bowles, P. 2013. 'Globalizing' northern British Columbia: What's in a word? Globalizations 10 (2), 261-276.

Boyd, D. 2003. Unnatural Law: Rethinking Canadian Environmental Law and Policy. UBC Press, Vancouver.

BP Exploration Canada Limited. 1979. BP Canada Inc. - Sukunka Coal Project Stage II Submission: Volume I Summary Document. Prepared for the Environment and Land Use Committee as prescribed by the Guidelines for Coal Development British Columbia.

Brasier, K., Filteau, M., McLaughlin, D., Jacquet, J., Stedman, R., Kelsey, T. and Goetz, S. 2011. Residents' perceptions of community and environmental impacts from development of natural gas in the Marcellus Shale: A comparison of Pennsylvania and New York cases. Journal 
of Rural Social Sciences 26 (1), 32-61.

Cheshire, I. 2010. A corporate responsibility? The constitution of fly-in, fly-out mining companies as governance partners in remote, mine-affected localities. Journal of Rural Studies $26(1), 12-20$.

Cinnabar Peak Mines Ltd. 1981. Coal Development Prospectus: The Peace River Canyon, A Presentation to the Province of British Columbia.

Cumbers, A., MacKinnon, D., and McMaster, R. 2003. Institutions, power, and space: Assessing the limits to institutionalism in economic geography. European Urban and Regional Studies 10 (4), 325-342.

Davis, H. and Hutton, T. 1989. The two economies of British Columbia. BC Studies 82, 3-15.

Denison Mines Limited. 1982. Belcourt Feasibility Study: Volume 6 - Environmental. Belcourt Coal Joint Venture.

Douglas Channel Energy Partnership. 2013. Available at http://douglaschannelenergy.com/ Accessed April $23^{\text {rd }}, 2013$.

Drache, D. 1991. Harold Innis and Canadian capitalist development. In: Laxer, G., Editor, Perspectives on Canadian Economic Development: Class, Staples, Gender, and Elites, pp. 2249. Oxford University Press Canada, Don Mills.

Drahokoupil, J. 2012. Beyond lock-in versus evolution, towards punctuated co-evolution: on Ron Martin's 'Re-thinking regional path dependence”. International Journal of Urban and Regional Research 36 (1), 166-171.

Edenhoffer, K. and Hayter, R. 2013a. Organizational restructuring in British Columbia's forest industries 1980-2010: The survival of a dinosaur. Applied Geography 45, 375-384.

Edenhoffer, K. and Hayter, R. 2013b. Restructuring on a vertiginous plateau: The evolutionary trajectories of British Columbia's forest industries 1980-2010. Geoforum 44, 139-151.

Essletzbichler, J. and Rigby, D. 2007. Exploring evolutionary economic geographies. Journal of Economic Geography 7, 549-571.

Everingham, J., Barnes, R. and Brereton, D. 2013. Gulf Communities Agreement 2008-2013. 15year Review.CSRM, The University of Queensland, Brisbane.

Gousseau, K. 2008, February 22. Terra Energy drops hot play. Alaska Highway News, p. A1.

Gunton, T. 1997. Forestry land use and public policy in British Columbia: The dynamics of change. In: Barnes, T. and Hayter, R., Editors, Trouble in the Rainforest: British Columbia's Forest Economy in Transition, pp. 65-74. Western Geographical Press, Victoria. 
Hak, G. 2007. Capital and Labour: In the British Columbia Forest Industry, 1934-74. UBC Press, Vancouver.

Haley, B. 2011. From staples trap to carbon trap: Canada's peculiar form of carbon lock-in. Studies in Political Economy 88, 97-132.

Halseth, G. and Sullivan, L. 2002. Building Community in an Instant Town: A Social Geography of Mackenzie and Tumbler Ridge, British Columbia. UNBC Press, Prince George, BC.

Halseth, G., Straussfogel, D., Parsons, S. and Wishart, A. 2004. Regional economic shifts in British Columbia: Speculation from recent demographic evidence. Canadian Journal of Regional Science 27 (3), 317-352.

Hamilton, G. 1999, January 7. Gold River needs bailout, study says: Forest minister pessimistic that a massive rescue effort along the lines of Skeena Cellulose is forthcoming. The Vancouver Sun, F1.

Hayter, R. 2008. Environmental economic geography. Geography Compass 2 (3), 831-850.

Hayter, R. 2004. Economic geography as dissenting institutionalism: The embeddedness, evolution and differentiation of regions. Geografiska Annaler B 86 (2), 95-1115.

Hayter, R. 2000. Flexible Crossroads: The Restructuring of British Columbia's Forest Economy. UBC Press, Vancouver.

Hayter, R. 1993. International trade and the Canadian forest industries: The paradox of the North American Free Trade Agreements. Zeitschrift fur Kanada-Studien 2, 81-94.

Hayter, R. 1982. Truncation, the international firm, and regional policy. Area 14, 277-282.

Hayter, R. and Barnes, T. 1997. The restructuring of British Columbia's coastal forest sector: Flexibility perspectives. In: Barnes, T. and Hayter, R., Editors, Troubles in the Rainforest: British Columbia's Forest Economy in Transition, pp. 181-203. Western Geographical Press, Victoria, BC.

HD Mining. 2013. Available at http://hdminingintl.com/ Accessed April 23 ${ }^{\text {rd }}, 2013$.

Heintzman, M. 2002, July 24. Williams plans to sell assets. Peace River Block Daily News, p. 2.

Holloway, T. 2008, January 8. High hopes not enough to support truck company; Industry slowdown runs the Real McCoy out of the city. Alaska Highway News, p. A1.

Hudson, R. 2006. The 'new' economic geography? In: Bagchi-Sen, S., and \& Smith, H., Editors, Economic Geography: Past, Present, and Future, pp. 47-55. Routledge, New York. 
Hutton, T. 2002. British Columbia at the Crossroads: New Regional Development Pathways for the $21^{\text {st }}$ Century. Vancouver: Report Prepared for Project 250, Regional Economies Expert Panel.

Innis, H. 1933. Problems of Staple Production in Canada. Ryerson Press, Toronto.

Innis, H. 1950. Empire and Communications. University of Toronto Press, Toronto.

Irwin, E., Isserman, A., Kilkenny, M. and Patridge, M. 2010. A century of research on rural development and regional issues. American Journal of Agricultural Economics 92(2): 522-553.

Kitimat LNG. 2013. Available at http://www.kitimatlngfacility.com/index.aspx Accessed April 23rd, 2013.

Lee, R. 2002. 'Nice maps, shame about the theory'? Thinking geographically about the economic. Progress in Human Geography 26 (3), 333-355.

Leyshon, A. 2011. Towards a non-economic, economic geography? From black boxes to the cultural circuit of capital in economic geographies of firms and managers. In: Leyshon, A., Lee, R., McDowell,L., and Sunley, P., Editors, The SAGE Handbook of Economic Geography, pp. 383-397. SAGE Publications, London.

LNG Canada Development Inc. 2013. Available at http://ngcanada.ca/ Accessed April 23 ${ }^{\text {rd }}$, 2013.

Mackenzie, S. and Norcliffe, G. 1997. Restructuring in the Canadian newsprint industry. The Canadian Geographer 41 (1), 2-6.

MacLeod, G. 2001. Beyond soft institutionalism: Accumulation, regulation, and their geographical fixes. Environment and Planning A 33, 1145-1167.

Marchak, P. 1983. Green Gold: The Forest Industry in British Columbia. UBC Press, Vancouver.

Markey, S., Halseth, G. and Manson, D. 2012. Investing in Place: Economic Renewal in Northern British Columbia. UBC Press, Vancouver.

Markey, S. and Heisler, K. 2011. Getting a fair share: Regional development in rapid boom-bust rural setting. Canadian Journal of Regional Science 33 (3), 49-62.

Martin, R. 2012. Re(placing) path dependence: A response to the debate. International Journal of Urban and Regional Research 36 (1), 179-192.

Martin, R. 2010. Roepke lecture in economic geography - rethinking regional path dependence: beyond lock-in to evolution. Economic Geography 86 (1), 1-27. 
Martin, R. 2000. Institutional approaches in economic geography. In: Sheppard, E. and Barnes, T., Editors, A Companion to Economic Geography, pp. 77-94. Blackwell Publishers, Oxford.

Martin, R. 1994. Economic theory and human geography. In: Gregory, D., Martin, R., and Smith, G., Editors, Human Geography: Society, Space, and Social Science, pp. 21-53. University of Minnesota Press, Minneapolis.

Michell, G. and McManus, P. 2013. Engaging communities for success: Social impact assessment and social license to operate at Northparkes Mines, NSW. Australian Geographer 44 (4), 435-459.

Ministry of Energy and Mines. 2013a. British Columbia's Liquefied Natural Gas Strategy. Province of British Columbia, Victoria, BC. Available on-line at: http://www.gov.bc.ca/ener/popt/down/liquefied_natural_gas_strategy.pdf.

Ministry of Energy and Mines. 2013b. British Columbia's Natural Gas Strategy. Province of British Columbia, Victoria, BC. Available on-line at: http://www.gov.bc.ca/ener/popt/down/natural_gas_strategy.pdf.

Ministry of Energy, Mines and Natural Gas. 2013. News Release. International interest remains high in Liquefied Natural Gas (LNG). Victoria, BC. April $10^{\text {th }}$. Available at http://www.newsroom.gov.bc.ca/2013/04/international-interest-remains-high-in-liquefiednatural-gas-lng.html Accessed April 23rd, 2013.

Mitchell, D. 1983. WAC Bennett and the Rise of British Columbia. Douglas \& MacIntyre, Vancouver.

Nee, V. 2005. The new institutionalisms in economics and sociology. In: Smelser, N. and Swedberg, R., Editors, The Handbook of Economic Sociology, pp. 49-74. Princeton University Press, Princeton, NJ.

Nelsen, J., Scoble, M. and Ostry, A. 2010. Sustainable socio-economic development in mining communities: North-central British Columbia perspectives. International Journal of Mining, Reclamation, and Environment 24 (2), 163-179.

Northern Sentinel. 2013, April 10. LNG Canada files. Northern Sentinel 58 (15), p. 1.

O'Faircheallaigh, C. 2013. Extractive industries and Indigenous peoples: A changing dynamic? Journal of Rural Studies 30, 20-30.

Oosterlynck, S. 2012. Path dependence: A political economy perspective. International Journal of Urban and Regional Research 36 (1), 158-165.

Ostergaard, P. 2002. Energy resources in BC's central interior. Western Geography 12, 216-229.

Owen, J.R. 2013. Social license and mining: A critical perspective. Resources Policy 38, 29-35. 
Paasi, A. 2009. The resurgence of the 'region' and 'regional identity': Theoretical perspectives and empirical observations on regional dynamics in Europe. Review of International Studies 35 (1), 121-146.

Paasi, A. 2002. Place and region: Regional worlds and words. Progress in Human Geography 26 (6), 802-811.

Pacific 66. 1978. Monkman Coal Project Prospectus.

Pacific Northwest LNG. 2013. Available at http://pacificnorthwestlng.com/ Accessed April $23^{\text {rd }}$, 2013.

Page, S. 2006. Path dependence. Quarterly Journal of Political Science 1, 87-115.

Page, B. 1996. Across the great divide: Agriculture and industrial geography. Economic Geography 72 (4), 376-397.

Peck, J. 2005. Struggling with the creative class. International Journal of Urban and Regional Affairs 29 (4), 740-770.

Peck, J. 2000. Doing regulation. In: Clar, G., Feldman, M., and Gertler, M., Editors, The Oxford Handbook of Economic Geography, pp. 61-80. Oxford University Press, Toronto.

Peet, R. 2007. Geography of Power: The Making of Global Economic Policy. Zed Books, London.

Petro-Canada Coal Division. Monkman Coal Project: Executive Summary.

Petronas. 2012. Available at http://petronas.com Accessed April 23rd, 2013.

Plummer, P. and Tonts, M. 2013. Geographical Political Economy, Dirt Research and the Pilbara. Australian Geographer 44 (3), 223-226.

Potts, R. 2010. The natural advantage of regions: Linking sustainability, innovation, and regional development in Australia. Journal of Cleaner Production 18, 713-725.

Prince George Citizen. 2009, June 16. Pair of deals; NuVista, Terra Energy buy oil, gas properties in northeastern BC. Prince George Citizen, p. 14.

Prince George Citizen. 2000, November 14. Gas plant set to close. Prince George Citizen, p. 6.

Prince George Free Press. 2013, December Special Edition: Northern Report. Development in a nutshell. LNG - new economy? A look at what drives the economy of Northern BC. Pp. A12 and A14. 
Province of British Columbia. 2012. Haisla Nation and Province of British Columbia: Lease of Crown Land to Haisla Nation for Industrial Development. Douglas Channel, British Columbia. Province of British Columbia, Victoria, BC. Available on-line at:

http://www.newrelationship.gov.bc.ca/shared/downloads/haisla_framework_agreement.pdf.

Reed, M. 2003. Taking Stands: Gender and the Sustainability of Rural Communities. UBC Press, Vancouver.

Russi, D., Gonzalez-Martinez, A., Silva-Macher, J., Giljum, S., Martinez-Alier, J. and Vallejo, M. 2008. Material flow in Latin America. Journal of Industrial Ecology 12 (5-6), 704-720.

Ryser, L. and Halseth, G. 2010. Rural economic development: A review of the literature from industrialized economies. Geography Compass 4 (6), 510-531.

Schafft, K., Borlu, Y. and Glenna, L. 2013. The relationship between Marcellus shale gas development in Pennsylvania and local perceptions of risk and opportunity. Rural Sociology 78 (2), 143-166.

Shell Global. 2012. Shell and partners announce LNG project in Canada. Media Release available on-line: http://www.shell.com/global/aboutshell/media/news-and-mediareleases/2012/lng-canada-15052012.html.

Sheppard, E. 2013. Thinking through the Pilbara. Australian Geographer 44 (3), 265-282.

Simandan, D. 2012. Rethinking the conceptual foundations of evolutionary economic geography: Introduction to a debate. International Journal of Urban and Regional Research 36 (1), 156-157.

Smyth, P., Reddel, T. and Jones, A. 2004. Social inclusion, new regionalism, and associational governance: The Queensland experience. International Journal of Urban and Regional Research 38 (3), 601-615.

Spectra Energy Corp. 2012a. News Release. Spectra Energy progressing on \$1.5 billion expansion program in British Columbia. Vancouver, BC. May $14^{\text {th }}$. Available at http://www.spectraenergy.com/Newsroom/News-Archive/Spectra-Energy-progressing-on-15billion-expansion-program-in-British-Columbia/ Accessed April $23^{\text {rd }}, 2013$.

Spectra Energy Corp. 2012b. 2012 Annual Report. Within Reach. Spectra Energy Corp., Houston, TX. Available at http://www.spectraenergy.com/content/documents/IR/2012_Annual_Report.pdf Accessed April $23^{\text {rd }}, 2013$.

Spectra Energy Corp. n.d. Spectra Energy proposes new natural gas system to build opportunities for British Columbia. Spectra Energy Corp.

Spectra Energy LNG. 2013. Available at http://www.spectraenergy.com/ Accessed April 23 ${ }^{\text {rd }}$, 2013. 
Stantec Consulting Ltd. 2013. Summary of the project description. Prepared for LNG Canada Project. LNG Canada Development Inc., Burnaby, BC.

Streek, W. and Thelen, K. (eds.) 2005. Beyond Continuity: Institutional Change in Advanced Political Economies. Oxford University Press, Oxford.

Swedberg, R. and Granovetter, M. 1992. Introduction. In: Granovetter, M. and Swedberg, R., Editors, The Sociology of Economic Life, pp. 1-26. Westview Press, Boulder, Colorado.

Taylor, A., Larson, S., Stoeckl, N. and Carson, D. 2011. The haves and have nots in Australia's tropical north - new perspectives on a persisting problem. Geographical Research 49 (1), 13-22.

Teck Corporation. 1981. Burnt River Coal Project: Stage 1 Report.

Tonts, M., Argent, N. and Plummer, P. 2012. Evolutionary perspectives on rural Australia. Geographical Research 50 (3), 291-303.

Tonts, M., Martinus, K. and Plummer, P. 2013. Regional development, redistribution and the extraction of mineral resources: The Western Australian goldfields as a resource bank. Applied Geography 45, 365-374.

United States Securities and Exchange Commission. 2013. Walter Energy, Inc. Annual Report pursuant to section 13 or 15(D) of the Securities Exchange Act 1934. Commission File Number 001-13711.

Utah Mines Ltd. 1976. Carbon Creek Coal Development: Prospectus.

Uyarra, E. 2010. What is evolutionary about 'regional systems of innovation'? Implications for regional policy. Journal of Evolutionary Economics 20, 115-137.

Walter, G. 1997. Staples, regional growth and community sustainability. In: T. Barnes and Hayter, R., Editors, Troubles in the Rainforest: British Columbia's Forest Economy in Transition, pp. 287-301. Western Geographical Press, Victoria, BC.

Walter Energy Inc. 2013. Available at http://www.walterenergy.com/ Accessed April 23 ${ }^{\text {rd }}, 2013$.

Watkins, M. 1982. The Innis tradition in Canadian political economy. Canadian Journal of Political Science and Social Theory 6 (1-2), 12-34.

Watkins, M. 1981. The Staple Theory revisited. In: Melody, W., Salter, L., and Heyer, P., Editors, Culture, Communication, and Dependency: The Tradition of H.A. Innis, pp. 53-71. Ablex Pub. Corp., Norwood.

Weaver, C. and Gunton, T. 1982. From drought assistance to megaprojects: Fifty years of regional theory and policy in Canada. The Canadian Journal of Regional Science 5 (1), 2-37. 
Williston, E. and Keller, B. 1997. Forests, Power, and Policy: The Legacy of Ray Williston. Caitlin Press, Prince George, BC.

Wilson, L. 2004. Riding the resource roller coaster: Understanding socioeconomic differences between mining communities. Rural Sociology 69 (2), 261-281.

Yaffe, B. 2013, April 11. For voters, temporary workers may be seen as political failure;

Politicians are expected to defend Canadian interests, including jobs. The Vancouver Sun, p. B2.

Yakovleva, N. 2005. Corporate Social Responsibility in the Mining Industries. Ashgate, Burlington. 


\section{Table 1a \\ Regional Coal Mining - 1980s}

\begin{tabular}{|c|c|c|c|c|}
\hline \multicolumn{5}{|c|}{ Round 1: 1980s } \\
\hline Project & Proponent & $\begin{array}{l}\text { \% Ownership } \\
\text { Share }\end{array}$ & Head Office* & Workforce \\
\hline \multicolumn{5}{|c|}{$\begin{array}{l}\text { Expressions of } \\
\text { Interest }\end{array}$} \\
\hline & BP Exploration Canada & - & UK & - \\
\hline & Cinnabar Peak Mines & - & Canada & - \\
\hline & Denison Mines Ltd. & - & Canada & - \\
\hline & Pacific 66 & - & US & - \\
\hline & Petro Canada & - & Canada & - \\
\hline & Teck Corporation & - & Canada & - \\
\hline & Utah Mines & - & US & - \\
\hline \multicolumn{5}{|c|}{ Developed Mines } \\
\hline Quintette & Denison Mines Ltd. & $100 \%$ & Canada & 1500 workers \\
\hline \multirow[t]{3}{*}{ Bullmoose } & Teck Corporation & $61 \%$ & Canada & 500 workers \\
\hline & Rio Algom Ltd. & $29 \%$ & Canada & \\
\hline & Nissho-Iwai Ltd. & $10 \%$ & Japan & \\
\hline
\end{tabular}


Table 1b

Regional Coal Mining - 2010s

\begin{tabular}{|c|c|c|c|c|}
\hline \multicolumn{5}{|l|}{ Round 2: 2010s } \\
\hline Project & Proponent & $\begin{array}{l}\text { \% Ownership } \\
\text { Share }\end{array}$ & Head Office* & Workforce \\
\hline \multicolumn{5}{|l|}{ Developed Mines } \\
\hline Trend & Anglo-American & $100 \%$ & UK & 450 workers \\
\hline Wolverine & Walter Energy & $100 \%$ & US & 430 workers \\
\hline Willow Creek & Walter Energy & $100 \%$ & US & 350 workers \\
\hline Brule & Walter Energy & $100 \%$ & US & 80 workers \\
\hline \multicolumn{5}{|l|}{ Proposed Mines } \\
\hline \multirow[t]{4}{*}{ Murray River } & $\begin{array}{l}\text { HD Mining } \\
\text { International Ltd. }\end{array}$ & & & 600 workers est \\
\hline & $\begin{array}{l}\text { Huiyong Holdings (BC) } \\
\text { Ltd. }\end{array}$ & $55 \%$ & China & \\
\hline & $\begin{array}{l}\text { Canadian Dehua } \\
\text { Lvliang International } \\
\text { Mines Corp. }\end{array}$ & $40 \%$ & China & \\
\hline & -unstated & $5 \%$ & -unstated & \\
\hline \multirow[t]{2}{*}{ Belcourt-Saxon } & Walter Energy & $50 \%$ & US & - \\
\hline & Anglo-American & $50 \%$ & UK & - \\
\hline EB & Walter Energy & $100 \%$ & US & - \\
\hline Hermann & Walter Energy & $100 \%$ & US & - \\
\hline Roman Mountain & Anglo-American & $100 \%$ & UK & - \\
\hline
\end{tabular}

* The identified head office locations are for each firm's parent company

- = not applicable

$\mathrm{n} / \mathrm{a}=$ not available

Anglo American 2013; Anglo American 2012; BP Exploration Canada 1979; HD Mining 2013; Cinnabar Peak Mines 1981; Denison Mines Limited 1982; Pacific66 1978; Petro-Canada n.d.; Teck Corporation 1981; United States Securities and Exchange Commission 2013; Utah Mines 1976; Walter Energy Inc 2013 
Table 2

Liquefied Natural Gas Export Plant Proposals

Proponents with Kitimat Terminal Plans

\begin{tabular}{|c|c|c|c|c|c|}
\hline Project & Proponent & $\begin{array}{l}\text { \% Ownership } \\
\text { Share }\end{array}$ & Head Office* & $\begin{array}{l}\text { Estimated } \\
\text { Production }\end{array}$ & $\begin{array}{l}\text { Estimated } \\
\text { Workforce }\end{array}$ \\
\hline \multirow[t]{4}{*}{ LNG Canada } & Shell Canada & $40 \%$ & Netherlands & $\begin{array}{l}12-24 \text { million } \\
\text { tonnes/yr }\end{array}$ & $\begin{array}{l}200-400 \\
\text { workers }\end{array}$ \\
\hline & $\begin{array}{l}\text { PetroChina } \\
\text { Company Ltd. }\end{array}$ & $20 \%$ & China & & \\
\hline & $\begin{array}{l}\text { Korea Gas } \\
\text { Corp. (KOGAS) }\end{array}$ & $20 \%$ & Korea & & \\
\hline & $\begin{array}{l}\text { Mitsubishi } \\
\text { Corp. }\end{array}$ & $20 \%$ & Japan & & \\
\hline \multirow{2}{*}{$\begin{array}{l}\text { Kitimat LNG \& } \\
\text { Pacific Trails } \\
\text { Pipeline }\end{array}$} & $\begin{array}{l}\text { Chevron } \\
\text { Canada }\end{array}$ & $50 \%$ & US & $\begin{array}{l}\text { 5-10 million } \\
\text { tonnes/yr }\end{array}$ & 50 workers \\
\hline & Apache Corp. & $50 \%$ & US & & \\
\hline \multirow{2}{*}{$\begin{array}{l}\text { BC LNG Export } \\
\text { Cooperative / } \\
\text { Douglas } \\
\text { Channel LNG } \\
\text { terminal }\end{array}$} & LNG Partners & $\mathrm{n} / \mathrm{a}$ & US & $\begin{array}{l}900,000- \\
1,800,000 \\
\text { tonnes/yr }\end{array}$ & $\mathrm{n} / \mathrm{a}$ \\
\hline & $\begin{array}{l}\text { HN DC LNG } \\
\text { Limited } \\
\text { Partnership } \\
\end{array}$ & $\mathrm{n} / \mathrm{a}$ & $\begin{array}{l}\text { Haisla Nation, } \\
\text { Canada }\end{array}$ & & \\
\hline \multirow[t]{2}{*}{ Triton LNG } & AltaGas Ltd. & $50 \%$ & $\begin{array}{l}\text { Calgary, } \\
\text { Alberta }\end{array}$ & $\begin{array}{l}2.3 \text { million } \\
\text { tonnes/yr }\end{array}$ & $\mathrm{n} / \mathrm{a}$ \\
\hline & $\begin{array}{l}\text { Idemitsu Kosan } \\
\text { Co. Ltd. }\end{array}$ & $50 \%$ & Tokyo, Japan & & \\
\hline
\end{tabular}

Proponents

with Prince

Rupert

Terminal Plans

\begin{tabular}{|c|c|c|c|c|c|}
\hline $\begin{array}{l}\text { Prince Rupert } \\
\text { LNG Proposal }\end{array}$ & Spectra Energy & $n / a$ & US & $\begin{array}{l}\text { 14-21 million } \\
\text { tonnes/yr }\end{array}$ & $\begin{array}{l}200-300 \\
\text { workers }\end{array}$ \\
\hline & BG Group & $\mathrm{n} / \mathrm{a}$ & UK & & \\
\hline $\begin{array}{l}\text { Pacific } \\
\text { Northwest LNG }\end{array}$ & PETRONAS & $n / a$ & Malaysia & $\begin{array}{l}12-18 \text { million } \\
\text { tonnes/yr }\end{array}$ & $\begin{array}{l}200-300 \\
\text { workers }\end{array}$ \\
\hline & $\begin{array}{l}\text { Progress } \\
\text { Energy Canada } \\
\text { Ltd. (wholly } \\
\text { owned by } \\
\text { PETRONAS) }\end{array}$ & $\mathrm{n} / \mathrm{a}$ & & & \\
\hline
\end{tabular}




\begin{tabular}{|c|c|c|c|c|c|}
\hline & $\begin{array}{l}\text { Japan } \\
\text { Petroleum } \\
\text { Exploration }\end{array}$ & $n / a$ & Japan & & \\
\hline \multicolumn{6}{|l|}{$\begin{array}{l}\text { Expressions of } \\
\text { interest for } \\
\text { available LNG } \\
\text { export terminal } \\
\text { site in Prince } \\
\text { Rupert }\end{array}$} \\
\hline \multirow[t]{4}{*}{ Aurora LNG } & $\begin{array}{l}\text { Nexen Inc } \\
\text { (wholly owned } \\
\text { subsidiary of } \\
\text { CNOOC) }\end{array}$ & $n / a$ & China & $\begin{array}{l}24 \text { million } \\
\text { tonnes/yr }\end{array}$ & - \\
\hline & CNOOC & $\mathrm{n} / \mathrm{a}$ & China & & \\
\hline & INPEX Corp. & $\mathrm{n} / \mathrm{a}$ & Japan & & \\
\hline & $\begin{array}{l}\text { JGC } \\
\text { Engineering }\end{array}$ & $\mathrm{n} / \mathrm{a}$ & Japan & & \\
\hline Woodside LNG & $\begin{array}{l}\text { Woodside } \\
\text { Petroleum Ltd. }\end{array}$ & $100 \%$ & Australia & - & - \\
\hline SKE \& S & SKE \& S & $100 \%$ & Korea & - & - \\
\hline \multirow[t]{2}{*}{$\begin{array}{l}\text { Imperial Oil / } \\
\text { ExxonMobil } \\
\text { Canada Ltd. }\end{array}$} & $\begin{array}{l}\text { Imperial Oil } \\
\text { Resources Ltd. }\end{array}$ & $\mathrm{n} / \mathrm{a}$ & US & $\begin{array}{l}30 \text { million } \\
\text { tonnes/yr }\end{array}$ & - \\
\hline & $\begin{array}{l}\text { Exxon Mobile } \\
\text { Canada Ltd. }\end{array}$ & $\mathrm{n} / \mathrm{a}$ & US & & \\
\hline
\end{tabular}

* The identified head office locations are for each firm's parent company $\mathrm{n} / \mathrm{a}=$ information not available

Apache Corporation 2013a; Apache Corporation 2013b; Apache Corporation 2012; Apache Corporation, and Chevron Canada Ltd 2013; BC LNG Export Co-Operative LLC 2011; Douglas Channel Energy Partnership 2013; Kitimat LNG 2013; LNG Canada Development Inc 2013; Ministry of Energy, Mines and Natural Gas 2013; Northern Sentinel 2013; Pacific Northwest LNG 2013; Petronas 2012; Prince George Free Press 2013; Shell Global 2012; Spectra Energy Corp 2012a; Spectra Energy Corp 2012b; Spectra Energy Corp n.d.; Spectra Energy LNG 2013; Stantec Consulting Ltd 2013 